\title{
THE CORRELATION OF TOTAL FLAVONOID AND TOTAL PHENOLIC WITH ANTIOXIDANT ACTIVITY OF SINGLE BULB GARLIC (Allium sativum) FROM TAWANGMANGU AND MAGETAN
}

\author{
Ika Buana Januarti*), Hudan Taufiq, Sulistyaningsih \\ Faculty of Medicine, Department of Pharmacy, Universitas Islam Sultan Agung, Jl. Raya \\ Kaligawe KM.4, 50112, Semarang
}

Received March 27, 2019; Accepted November 11, 2019

\begin{abstract}
Flavonoids and phenolics are compounds with hydroxyl groups (-OH) bound to aromatic rings which enable them to react with reactive oxygen species and eliminate free radical activity. Single bulb garlic (Allium sativum var. solo garlic) is known to have antioxidant activity which comes from the phenolic groups. This study aims to determine the correlation of total flavonoid and phenolic levels with the antioxidant activity of ethanolic extracts from single bulb garlic grown in Magetan and Tawangmangu regions. This study included an observational analytic study with a cross-sectional design. Total flavonoid levels were measured by colorimetric method and total phenolic levels were measured by FolinCiocalteu method using Spectrophotometry UV-Vis. Antioxidant activity was measured by DPPH method at a wavelength of $517 \mathrm{~nm}$. The data analysis used was multiple linear regression. The results showed that the extract of single bulb garlic from Magetan had total flavonoids of $12.1833 \pm 0.1943 \mathrm{mg}$ QE/gram, total phenolics of $70.244 \mathrm{mg}$ GAE/gram, and antioxidant activity with an $\mathrm{IC}_{50}$ value of $20,216 \mathrm{ppm}$. The extract of single bulb garlic from Tawangmangu contained total flavonoids of $14.4833 \pm 0.5911 \mathrm{mg}$ QE/gram, total phenolics of $92.222 \mathrm{mg} \mathrm{GAE} / \mathrm{gram}$, and antioxidant activity with an $\mathrm{IC}_{50}$ value of $13.777 \mathrm{ppm}$. The conclusion of this study is that there is a significant correlation of total flavonoid and total phenolic content with antioxidant activity.
\end{abstract}

Keywords: antioxidant; flavonoid; garlic; phenolic

\section{INTRODUCTION}

Natural antioxidants can protect the body from free radical attacks and can slow the occurrence of chronic diseases caused by an increase in reactive oxygen species (ROS) especially hydroxyl radicals and superoxide radicals (Wahdaningsih et al., 2011). According to Paravicini and Touyz (2008), the increase in ROS production, known as oxidative stress, affects various diseases such as hypertension, diabetes, heart failure, stroke, atherosclerosis, and other chronic diseases. It is predicted that in 2030 more than two thirds $(70 \%)$ of the population or 52 million deaths per year will be due to degenerative diseases (Kemenkes RI, 2012).
One of the plants known to produce potential antioxidant activity is single bulb garlic (Allium sativum var.solo garlic) because it has the main phytochemicals content of sulfur compounds, peptides, steroids, terpenoids, flavonoids, and phenols (Agarwal, 1996). According to a study carried out by Prasonto et al., (2017), single bulb garlic has $\mathrm{IC}_{50}$ values of 10.61 $\mathrm{mg} / \mathrm{ml}$ which means that it has stronger antioxidant effect and is significantly different from $\mathrm{IC}_{50}$ values of garlic which is $13.61 \mathrm{mg} / \mathrm{ml}$. IC 50 values are influenced by the content of secondary metabolites such as phenolics. Phenolics have the ability as antioxidants because they can transfer an electron to a radical compound (Zuraida et al., 2017). The production of secondary

*Corresponding author: Ika Buana Januarti

Email: januarti@unissula.ac.id 
metabolites and antioxidant activity is influenced by different growth sites where different growth places affect the environmental temperature and biochemical processes found in plants causing the content of secondary metabolites such as phenolic will be different (Sholekah, 2017). If the total phenolic content in ethanolic extract of single bulb garlic is different, it can affect its antioxidant activity.

Based on the description above, a study investigating the correlation of total flavonoid and total phenolic content with the antioxidant activity of single bulb garlic ethanolic extract (Allium sativum var.solo garlic) is essential to carry out. Single bulb garlic used in this study is originated from Magetan and Tawangmangu area with considerations of the growing habitat temperature, soil $\mathrm{pH}$, air humidity, and altitude of different places.

\section{METHODS}

\section{Instrumentations and Materials}

Instrumentations used in this research were glassware, rotary evaporator (Heidolph), water bath (Memmert), moisture analyzer (Shimadzu), analytical balance (Mettler Toledo), and spectrophotometer UV-Vis (Genesys 10 UV scanning Thermo electron co). The materials used in this research were single garlic bulb, 96\% ethanol (E. Merck), DPPH (2.2-diphenyl-1-picrylhydrazyl) (SigmaAldrich.), aquadest (technical), 95\% quercetin (Sigma. Co.), 97.5-102.5\% gallic acid (Sigma. Co.), 99.9\% Folin-Ciocalteau (E. Merck), 98.5\% Mg powder (E. Merck), 99.9\% Methanol (E. Merck), 37\% $\mathrm{HCl}$ solution (E. Merck), $10 \% \mathrm{FeCl}_{3}$ (E. Merck) and $10 \% \mathrm{AlCl}_{3}$ (E. Merck).

\section{Identification of the Plant}

The specifications of the selected Allium sativum var solo garlic are having white color, single bulb, and fresh bulb. The origins of the plants are from Magetan (Wonomulyo village) with an altitude of 1,300 meters and Tawangmangu
(Gondosuli village) with an altitude of 1,200 meters. Plants identification took place at Biology Laboratory, Universitas Negeri Semarang.

\section{Extract Production}

Allium sativum var solo garlic obtained from Tawangmangu and Magetan were cleaned using running water and dried with aerated. The fresh bulb was chopped up with ethanol $96 \%$ then it was extracted by maceration method using ethanol $96 \%$ for $3 \times 24$ hours while stirring periodically. The liquid extract was filtered then concentrated using rotary evaporator. The process continued with water bath until viscous extract was obtained.

\section{Characterization of the Extract}

Organoleptic and phytochemical screening method was chosen for characterization of the extract. Organoleptic test was administered using human senses starting from the shape, smell, and color.

\section{Phytochemical Screening of Flavonoid and Phenolic}

One gram of single garlic bulb ethanolic extract was added with 5 drops of ethanol then shaken until it got homogeneous. This mixture was added with $\mathrm{Mg}$ powder and $\mathrm{HCl}$. Flavonoid content was identified by color changing into green, yellow, or red (Atmoko \& Ma'ruf, 2009).

As much as 0.5 gram of single garlic bulb ethanolic extract was dissolved with methanol then shaken until it became homogeneous. This mixture was added with $\mathrm{FeCl}_{3}$ reagent. Phenolic content could be identified by color changing into green, blue, or black (Atmoko and Ma'ruf, 2009). 


\section{Determination of Total Flavonoid}

Total flavonoid content was determined using colorimetric assay with modification based on the procedure of (Chang et al., 2002). Firstly, preparation for stock solution quercetin standard was completed. $1 \mathrm{mg}$ of quercetin was dissolved in $10 \mathrm{ml}$ of ethanol p.a (100 ppm) and was subsequently diluted to $10,20,30,40$ and $50 \mathrm{ppm}$. Quercetin as standard solution (1 ml) was added with $0.1 \mathrm{ml} \mathrm{AlCl}_{3} 10 \%$ and $0.1 \mathrm{~mL}$ potassium acetate $1 \mathrm{M}$. It was then incubated for 30 minutes at room temperature. In addition, absorbance was measured at maximum wavelength of 434 $\mathrm{nm}$. Secondly, preparation for extract solution was accomplished. $100 \mathrm{mg}$ extract was dissolved in $10 \mathrm{~mL}$ of ethanol p.a. (10.000 ppm). $1 \mathrm{ml}$ stock solution was taken and the volume was made into $10 \mathrm{ml}$ by adding ethanol p.a. with $0.1 \mathrm{~mL}(1000$ ppm). Each quercetin solution was added with $0.1 \mathrm{ml} \mathrm{AlCl} \mathrm{Al}_{3} 10 \%$ and $0.1 \mathrm{~mL}$ potassium acetate $1 \mathrm{M}$. It was then incubated for 30 minutes. Absorbance was measured at maximum wavelength $434 \mathrm{~nm}$. The extract solution was made in three replications. The TFC was expressed in $\mathrm{mg}$ Quercetin Equivalent (QE)/gram. Data obtained from the absorbance value of each sample were plotted into standard quercetin and calculated using the following formula.

$$
T F C=\frac{c x V}{m}
$$

In the above formula, $\mathrm{c}$ is concentration from calibration curve, $\mathrm{V}$ is extract volume, and $\mathrm{m}$ is extract mass.

\section{Determination of Total Phenolic Content}

The total phenolic content (TPC) was determined using Folin-Ciocalteou method. The first step was the preparation of gallicacid solution as standard solution. The stock solution was made into 100 ppm gallic-acid standard and was subsequently diluted to 10, 20, 30, 40 and $50 \mathrm{ppm}$. Each standard of solution $(2 \mathrm{ml})$ was added with $5 \mathrm{~mL}$ aquadest, $0.5 \mathrm{~mL}$ Folin Ciocalteau $50 \%$ reagent mixture with vortex. Next, it was incubated at temperature between 20- $25^{\circ} \mathrm{C}$ for 5 minutes. The mixture was added with $1 \mathrm{~mL} \mathrm{Na} \mathrm{CO}_{3} 20 \%$ and incubated at room temperature for 60 minutes. Absorbance was also measured at a maximum wavelength of $784 \mathrm{~nm}$.

The second step was preparation of Allium sativum var solo garlic solution extract weighed $15 \mathrm{mg}$. It was then dissolved in $10 \mathrm{~mL}$ of ethanol p.a. (150 $\mathrm{ppm})$. The $2 \mathrm{ml}$ of solution was added with $5 \mathrm{~mL}$ aquadest and $0.5 \mathrm{~mL}$ Folin Ciocalteau $50 \%$ reagent mixture with vortex. It was incubated at $20-25^{\circ} \mathrm{C}$ for 5 minutes. That mixture was added with $1 \mathrm{~mL} \mathrm{Na} \mathrm{CO}_{3} 20 \%$ and was incubated at room temperature for 60 minutes. The extract solution was made in three replications. Furthermore, absorbance was measured at a maximum wavelength of $784 \mathrm{~nm}$. The TPC (total phenolic content) was expressed in $\mathrm{mg}$ Gallic-acid Equivalent (GAE)/gram. TPC data obtained from the absorbance value of each sample were plotted into standard Gallic-acid and then calculated using the following formula.

$$
T P C=\frac{c x V}{m}
$$

In the above formula, $\mathrm{c}$ is concentration from calibration curve, $\mathrm{V}$ is extract volume and $\mathrm{m}$ is extract mass (Zuraida et al., 2017).

\section{Antioxidant Activity Assay with DPPH method}

One hundred mg extract was diluted with $100 \mathrm{~mL}$ ethanol p.a (stock solution). Sample from the extract stock solution and vitamin $\mathrm{C}$ were prepared in five different concentrations. $1 \mathrm{ml}$ sample was added with $3 \mathrm{ml}$ DPPH and ethanol until it reached $5.0 \mathrm{ml}$. The mixture was kept in the dark for 30 minutes. The absorbance at $\lambda$ maximum was recorded to determine the concentration of the remaining DPPH. The DPPH inhibition percentage of the test sample and the known solution were calculated using the following formula.

Scavenging effect $(1 \%)=\left(1-\frac{A i}{A C}\right) \times 100$ 
In the above formula, $\mathrm{Ai}$ is absorbance of the sample and Ac is absorbance of the blank at $\lambda$ maximum (Amin, 2015) .

\section{RESULTS AND DISCUSSION}

The identification results of Allium sativum are species of Allium sativum L., varieties of Allium sativum var. Sativum, and cultivar of Allium sativum L. Ctv. Solo (Biology Lab Universitas Negeri Semarang) with letter determination number of 657/UN/37.1.4.5/LT/2018.

\section{Phytochemical Screening of Flavonoid and Phenolic}

Single garlic bulb ethanolic extract had a specific smell, viscous extract, and brown-yellow color. The extract was identified as flavonoid because when it was added with $\mathrm{Mg}$ powder and $\mathrm{HCl}$, it made bubble $\left(\mathrm{H}_{2}\right.$ gas) and flavilium sodium until it changed into yellow. The extract was also identified as phenolic because it resulted in a blue coloration within the addition of ferric chloride (Atmoko \& Ma'ruf, 2009).

\section{Total Flavonoid Content (TFC)}

Determination of TFC was completed using a UV-Vis spectrophotometer with maximum absorption of $434 \mathrm{~nm}$. Quercetin was chosen as a standard because it is reported from Ouzounidou et al. (2011) that Allium vegetables, particularly common onion and garlic, are extremely abundant in flavonoids especially quercetin. TFC was determined based on colorimetric method using $\mathrm{AlCl}_{3}$. Colorimetric is the common method for calculating total flavonoid content such as in purified extract of Piper crocatum Ruiz and Pav (Januarti \& Wijayanti, 2018) and teak leaf ethanolic extract (Januarti et al., 2017). The principle is that $\mathrm{AlCl}_{3}$ forms an acid complex which is stable with C-4 ketone groups, C-3 or C-5 hydroxyl groups from flavones and flavonols (Chang et al., 2002). TFC of single garlic bulb extract from Magetan and Tawangmangu is presented in Table I.
Table I. TFC and TPC from Magetan and Tawangmangu

\begin{tabular}{ccc}
\multicolumn{3}{c}{ Tawangmangu } \\
\hline Origin & TFC $(\mathrm{mg}$ & $\mathrm{TPC}(\mathrm{mg}$ \\
& $\mathrm{QE} / \mathrm{g}) \pm$ & $\mathrm{GAE} / \mathrm{g}) \pm$ \\
& $\mathrm{SD}$ & $\mathrm{SD}$ \\
\hline Magetan & $12.1833 \pm$ & $70.2444 \pm$ \\
& 0.1943 & 1.2006 \\
\hline Tawangmangu & $14.4833 \pm$ & $92.2222 \pm$ \\
& 0.5991 & 1.8201 \\
\hline
\end{tabular}

TFC of single garlic bulb extract from Tawangmangu was higher than those from Magetan. TFC could be different because single garlic bulb extract from Magetan and Tawangmangu grew in different altitude, environment temperature, soil $\mathrm{pH}$, and air humidity. Single garlic bulb in Tawangmangu grew in altitude of 1,200 meters, environment temperature of $20^{\circ} \mathrm{C}$, soil $\mathrm{pH}$ of 6.8 , and air humidity of $80 \%$. Single garlic bulb in Magetan grew in altitude of 1,300 meters, environment temperature of $18^{\circ} \mathrm{C}$, soil $\mathrm{pH}$ of 6.5 and air humidity of $77 \%$.

The correlation was that TFC was decreasing from lower to higher altitudinal zones. Malinikova, et al. (2013) reported similar results from Fragaria vesca species with strong correlation between TFC and altitude. TFC and distribution of flavonoids are influenced by not only the altitude of the growth place but also genetic and various environmental factors such as light, humidity, and soil fertility (Malinikova et al., 2013).

\section{Total Phenolic content (TPC)}

Method used to determine total phenolic content is based on the strength of reducing the hydroxy groups of phenolic compounds. All phenolic compounds, including simple phenols, can react with Folin-Ciocalteu reagents (Alfian \& Susanti, 2012). Gallic acid is used as a comparative compound because gallic acid is a heteropoly acid which has 3-hydroxy phenolic groups. The hydroxy phenolate group will be oxidized by Folin-Ciocalteu reagent in an alkaline atmosphere. The hydroxyl group has a function as a 
contributor to hydrogen atoms when reacting with radical compounds through an electron transfer mechanism so that the oxidation process can be inhibited. Therefore, TPC is intended to find out the number of phenolic compounds in single garlic bulb extract which has antioxidant activity. TPC of single garlic bulb extract from Tawangmangu is higher than Magetan based on Table I.

Different TPC between single garlic bulb from Tawangmangu and Magetan could be due to different growth habitat. Single garlic bulb in Tawangmangu grew in altitude of 1,200 meters, environment temperature of $20^{\circ} \mathrm{C}$, soil $\mathrm{pH}$ of 6.8 and air humidity of $80 \%$. Single garlic bulb in Magetan grew in altitude of 1,300 meters, environment temperature of $18^{\circ} \mathrm{C}$, soil $\mathrm{pH}$ of 6.5 and air humidity of $77 \%$.

Chen et al. (2013) reported similar results that variability of TPC and TFAC in bulbs of different cultivars could be attributed to various cultivar characteristics. In agreement with our results, previous reports have shown that different garlic cultivars had different yields, allicin content (Khar et al., 2011), and polyphenolic content (Lu et al., 2011). These results are in accordance with total phenolic acid content of a local garlic cultivar grown near Namhae-gun, Korea. Its total phenolic acid content was 17.86 $\mathrm{mg} / \mathrm{kg}$ of dry matter $(\mathrm{dm})$ and the total flavonoid content was $29.95 \mathrm{mg} / \mathrm{kg} \mathrm{dm}$ (Kim JS \& Kang OJ, 2013). The total phenolic content varied from $3.4 \mathrm{mg}$ gallic acid equivalents (GAE) $/ \mathrm{g} \mathrm{dm}$ to $10.8 \mathrm{mg}$ GAE/g dm in different garlic cultivars grown at four locations in Andalusia, Spain (Beato VM et al., 2011). Total phenolics of red onion var. Rouge Amposta were reported by Benkeblia (2005) from 18 to 20 $\mathrm{mg} / 100 \mathrm{~g}$ fresh weight. The content of phenolic compounds in garlic, thus, varies greatly within genetic, agronomic, and environmental factors (Beato VM et al., 2011).

\section{Antioxidant Activity}

Antioxidant activity of single garlic bulb extract is presented in Table II and is classified as very strong because it has $\mathrm{IC}_{50}$ value of less than $50 \mathrm{ppm}$ (Mardawati et al., 2008). Antioxidant activity of single garlic bulb extract from Tawangmangu was stronger than Magetan in correlation with TFC and TPC. The correlation was that antioxidant activity was increasing along with TFC and TPC from higher to lower concentration.

Table II. IC $_{50}$ values of Single Garlic Bulb Extract

\begin{tabular}{ccc}
\hline Replicates & \multicolumn{2}{c}{$\mathrm{IC}_{50}(\mathrm{ppm})$} \\
\cline { 2 - 3 } 1 & Magetan & Tawangmangu \\
\cline { 2 - 3 } & 20.3333 & 13.8759 \\
\hline 2 & 20.1626 & 13.8281 \\
\hline 3 & 20.1600 & 13.6153 \\
\hline Average & 20.2186 & 13.7731 \\
\hline SD & 0.0993 & 0.1387 \\
\hline
\end{tabular}

Our results are in agreement with the report from Benkeblia (2005) stating that garlic extract showed higher radical scavenging activity and reducing capacity than green onion extract. These properties were significantly correlated to total phenolics content which was high in garlic. Sulfur compounds could be involved in the assessment of the antioxidant properties.

\section{Correlation between total flavonoids content and total phenolic contents, and antioxidant Activity}

Garlic possesses potential healthpromoting effects due to its high phenolic phytochemical content and is a source of natural antioxidants (Nuutila AM et al., 2003). Garlic is a source of various biologically active phytomolecules including organosulfur compounds, phenolic acids, allyl thiosulfinates, flavonoids, and vitamins. Antioxidant activity of flavonoids and phenolic is influenced by functional group that binds to its main structure. Flavonoids has mechanism of capturing free radicals (hydroxyl radicals, superoxide, and peroxyl) and inhibiting various oxidation reactions because they can produce phenolic radicals which are stabilized by 
resonance effect of aromatic rings (Ahmad et al., 2015). In other words, flavonoids stabilize reactive oxygen species by reacting with reactive compound of the radical (Hamidu et al., 2018).

Data analysis to show the correlation between TFC and TPC, and antioxidant activity was accomplished using multiple regression analysis. The results were presented in Table III. The analysis showed that there was a correlation between TFC and TPC, and antioxidant activity of single bulb garlic from Magetan and Tawangmangu. This is indicated by the significant value $(\mathrm{p}<0.05)$.

Shahwar et al. (2010) also reported that antioxidant activity was positively correlated with TFC and TPC. TFC and TPC were increasingly relevant to its antioxidant activity. The pharmacological activity of garlic depends on its bioactive compounds and more especially on its phenolic compounds (Lanzotti, 2006) (Corzo-Mart1'nez \& Corzo, 2007) in which interesting pharmacological properties are present in relatively high amounts (Beato VM et al., 2011).

Antioxidant activity in garlic was researched in protection against oxidative DNA damage, decreasing fibrinogen, reducing the risk of chronic diseases, preventing disease progression, and preventing cancer (Park \& Park, 2009; Shukla, 2007 ; Jastrzebski et al., 2007). Mohsen and Ammar's (2009) research shows that the radical capture activity tested on flavonoids and phenolics is related to the number and position of the hydroxyl group $(\mathrm{OH})$ bonds in the molecule. Increasing number of hydroxyl groups substituted in the molecule causes higher antioxidant ability because many hydrogen atoms can be donated (Yu Lin et al., 2009).

According to Zuraida et al., (2017), phenolic compounds contribute to antioxidant activity. Benkeblia (2000) reported similar results for garlic extract with high correlation between reducing power and total phenolics content with a determination coefficient $\left(\mathrm{r}^{2}\right)$ of 1.7. Statistical analysis also showed that radical scavenging activity, reducing capacity, scavenging of hydrogen peroxide and chain-breaking activity (initial and after heating) were highly correlated with total phenolics content of garlic extracts with coefficients of determination $\left(\mathrm{r}^{2}\right)$ ranging from 0.90 to 0.95 .

\section{CONCLUSION}

Based on the research that has been conducted, antioxidant activity of single bulb garlic (Allium sativum var.solo garlic) from Tawangmangu and Magetan was correlated with the presence of total flavonoid and total phenolic content. It was shown that single garlic bulb from Tawangmangu had higher TFC and TPC than those from Magetan, which was consistent with their antioxidant activity.

\section{ACKNOWLEDGMENT}

We would like to thank Institute Research and Community Service of Sultan Agung Islamic University for granting this research through internal research program.

Table III. Multiple Regression Analysis of EEUBL Magetan and Tawangmangu

\begin{tabular}{cccc}
\hline EEUBL & $\begin{array}{c}\text { Total Flavonoid toward } \\
\text { Antioxidant Activity }\end{array}$ & $\begin{array}{c}\text { Total Phenolic toward } \\
\text { Antioxidant Activity }\end{array}$ & $\begin{array}{c}\text { Total Flavonoid and Total Phenolic } \\
\text { toward Antioxidant Activity }\end{array}$ \\
\hline Magetan & $0.037^{*}$ & $0.022^{*}$ & $0.000^{*}$ \\
\hline Tawangmangu & $0.014^{*}$ & $0.027^{*}$ & $0.001^{*}$ \\
\hline
\end{tabular}

*significant $(\mathrm{p}<0.05)$ 


\section{REFERENCES}

Ahmad, R. A., Juwita., Ratulangi, S. A., Malik, A., 2015. Penetapan Kadar Fenolik dan Flavonoid Total Ekstrak Metanol Buah dan Daun Patikala (Etlingera elatior (Jack). Pharm Sci Res, II(1).

Alfian, R., Susanti, H., 2012. Penetapan Kadar Fenolik Total Ekstrak Metanol Kelopak Bunga Rosella Merah (Hibiscus sabdariffa Linn) dengan Variasi Tempat Tumbuh Secara Spektrofotometri. Jurnal Ilmiah Kefarmasian, 2(1), 73-80.

Amin, S., 2015. Uji Aktivitas Antioksidan Umbi Bawang Lanang (Allium sativum) terhadap Radikal Bebas DPPH. Jurnal Kesehatan Bakti Tunas Husada, 3(1).

Atmoko, T., Ma'ruf, A., 2009. Uji Toksisitas dan Skrining Fitokimia Ekstrak Tumbuhan Sumber Pakan Orang utan Terhadap Larva Artemia salina L. Jurnal Penelitian Hurtan dan Konservasi Alam, VI(1).

Beato VM, Orgaz F, Mansilla F, M.A., 2011. Changes in phenolic compounds in garlic (Allium sativum L.) owing to the cultivar and location of growth. Plant Food Hum Nutr, 66(3), 218-223.

Benkeblia, N., 2005. Free-Radical Scavenging Capacity and Antioxidant Properties of Some Selected Onions (Allium cepa L .) and Garlic (Allium sativum L.) Extracts 48(September), 753-759.

Chang, C. C., Yang, M. H., Wen H. M., Chern, J.C., 2002. Estimation of Total Flavonoids Content in Propolis by Two Complementary Colorimetric Methods. J Food Drug Anal, 10.

Chen, S., Shen, X., Cheng, S., Li, P., Du, J., Chang, Y., 2013. Evaluation of Garlic Cultivars for Polyphenolic Content and Antioxidant Properties 8(11).
Corzo-Mart1 'nez M, Corzo N, V.M., 2007. Biological properties of onions and garlic. Trends Food Sci Tech, 18(12), 609-625.

Hamidu, L., Ahmad, A.R., Najib, A., Hamidu, L., Ahmad, R., 2018. Qualitative and Quantitative Test of Total Flavonoid Buni Fruit (Antidesma bunius ( L .) Spreng ) with UV-Vis Spectrophotometry Method 10(1), 60-63.

Januarti, I.B., Santoso, A., Razak, A.S., 2017. Flavonoid Extraction of Teak Leaf ( Tectona grandis L .) with Ultrasonic Method (Study Of Material: Solvent Ratio and Extraction Time ). Media Farmasi Indonesia, 12(2), 12631270.

Januarti, I.B., Wijayanti, R., 2018. Kadar Flavonoid Ekstrak Terpurifikasi Daun Sirih Merah (Piper crocatum Ruiz and Pav .). Motorik Jurnal Ilmu Kesehatan, 13(27), 92-99.

Jastrzebski Z, Leontowicz H, Leontowicz M, Namiesnik J, Z.Z., 2007. The bioactivity of processed garlic (Allium sativum L.) as shown in vitro and in vivo studies on rats. Food Chem Toxicol, 45(9), 16261633.

Khar, A. , Banerjee, K., Jadhav, M.R., Lawande, K.E., 2011. Evaluation of garlic ecotypes for allicin and other allyl thiosulphinates. Food Chemistry, 128(4), 988-996.

Kim JS, Kang OJ, G.O., 2013. Comparison of phenolic acids and flavonoids in black garlic at different thermal processing steps. J Funct Foods, 5(1), 80-86.

Lanzotti, V., 2006. The analysis of onion and garlic. $J$ Chromatogr $A$, 1112(1), 3- 22.Lu X, Wang J, Aston, DE, Ross CF, Powers JR, R.B., 2011. et al. (2011) Determination of Total Phenolic Content and Antioxidant Activity 
of Garlic (Allium sativum) and Elephant Garlic (Allium ampeloprasum) by Attenuated Total Reflectance-Fourier. Journal of Agricultural and Food Chemistry, 59(10), 5215-5221.

Malinikova, E., Kukla, J., Kuklová, M., Balazova, M., 2013. Altitudinal Variation of Plant Traits: Morphological Characteristics in Rosaceae (Fragaria vesca L.). Annals of Forest Research, 56(1), 79-89.

Mardawati, E., Achyar, C.S, Marta, H., 2008. Kajian Aktivitas Antioksidan Ekstrak Kulit Manggis dalam Rangka Pemanfaatan Limbah Kulit Manggis di Kecamatan Puspahiang Kabupaten Tasikmalaya. Universitas Padjajaran,

Mohsen, S.. \& A.A.S.M., 2009. Total phenolic contents and antioxidant activity of corn tassel extracts. Food Chemistry, 112(3), 595598.

Nuutila AM, Puupponen-Pimia“ R, Aarni M, O.-C.K., 2003. Comparison of antioxidant activities of onion and garlic extracts by inhibition of lipid peroxidation and radical scavenging activity. Food Chem, 81(4), 485-493.

Ouzounidou, G., Giannakoula, A., Asfi, M., Ilias, I., 2011. Differential Responses Of Onion And Garlic Against Plant Growth Regulators 43(4), 2051-2057.

Shahwar, D., Ahmad, N., Ullah, S., Raza, M.A., 2010. Antioxidant Activities of the Selected Plants from the Family Euphorbiaceae, Lauraceae, Malvaceae and Balsaminaceae. Journal of Biotechnology, 9(7), 1086-1096.

Shukla, Y., K.N., 2007. Cancer chemoprevention with garlic and its constituents. Cancer Letters, 247(2), 167-181.

Yu Lin, H., Kuo, Y.H. Lin., Y.L. \& Chiang, W., 2009. Antioxidative Effect and Active Components from Leaves of Lotus (Nelumbo nucifera). Journal of Agricultural and Food Chemistry, 57(15), 6623-6629.

Zuraida., Sulistiani., Sajuthi, D., Irma H. S., 2017. Fenol, Flavonoid, dan Aktivitas Antioksidan pada Ekstrak Kulit Batang Pulai (Alstonia scholaris R.Br). Penelitian Hasil Hutan, 35(3). 